\title{
Cognitive script as model of subsumption of linguistic knowledge
}

\author{
Modal verbs in the modern German language
}

\author{
O. M. Egorova \\ Murom Institute (branch) of Vladimir State University \\ Murom, Russia \\ egorovaom45@mail.ru
}

\begin{abstract}
The article deals with the cognitive model of the realization of grammar meaning and the activity modality of modal verbs in the modern German language. Every modal verb objectifies its cognitive script and it reflects deictic or non-deictic way of usage of modals.
\end{abstract}

Keywords-cognitive grammar, conceptualization, cognitive script, grammar precedent unit, deontic modality, epistemic modality

\section{INTRODUCTION}

This article is devoted to consideration of the modal verbs of the German language in the framework of cognitive grammar, more precisely, the precedent grammar - the grammar of derived linguistic facts. According to one of the leading positions of precedent grammar, the precedent character of a grammatical unit can be found in its form, meaning or function that does not exclude the possibility of realizing its feature in all semiotic aspects at once $[1,2]$.

Cognitive grammar by many provisions is similar to other grammatical and / or cognitive concepts, but it has differences because of the aspiration to create a more complete picture of the structuring and the functioning of the grammatical phenomena, paying at the same time the main attention to the phenomenon of meaning in the world conceptualization.

Development of theoretical basis for the explanation of the functions of the modal verbs in the German language is based on the postulate of grammatical polysemy and synonymy. This postulate allowed speaking about the precedent (secondary) meanings of the modal verbs and their consideration in cognitive grammar.

\section{PROCESSES OF CONCEPTUALIZATION AND CATEGORIZATION}

Processes of conceptualization and categorization of the reality are the fundamental processes of understanding the person in it. They are "key concepts in describing the cognitive activity and cognitive abilities of a person" [3] and they articulate the leading postulates of cognitive linguistics as a special paradigm of modern linguistics.

The knowledge of the worldviews through two fundamental processes - conceptualization and categorization allows the modern researches to solve problems related to general and particular features of the correlation of linguistic structures with mentally. There is an opportunity to identify typological and specific features of the expression language as "instruments of access to mental, cognitive, intellectual and interiorizing activities in the head of a person [4].

The emergence of cognitive linguistics is caused by a new understanding of the language and underlining its physic and mental aspect in it. As a section of linguistics, cognitive linguistics is connected with the study of cognition (as a process and a result of knowledge) in its linguistic aspects and manifestations, on the one hand, and with the study of the cognitive aspects of the lexical, grammatical and other phenomena themselves, on the other [5].

Today in the framework of cognitive linguistics, there are linguistic areas, such as cognitive lexicology, cognitive phonetics, cognitive semantics, cognitive grammar and others.

The focus of the new field of theoretical and applied linguistics is cognitive aspects of linguistic phenomena of different language levels and the role of the language in cognitive processes and the generalization of human experience.

The special role of cognitive linguistics is seen by linguists in strong and conscious desire to "recontextualize grammar", which aims to restore the relations of grammar with vocabulary, social and cultural context [6].

At the present, cognitive grammar solves a number of linguistic problems, one of which is the study of the precedent (secondary) meaning which is a cognitive base of the precedent grammatical meanings [1].

Cognitive grammar is analyzed in a wide and narrow sense. Cognitive grammar in the wide sense is understood as a set of grammatical concepts and grammatical models of description languages. The essence of the latter is "in consideration of cognitive aspects of linguistic phenomena, i.e. of explanation in interactions with processes of cognizing the world and such cognitive phenomena as perception, memory, thinking, etc. [5]. 
In a narrow sense, cognitive grammar refers to a particular type of grammatical description of the language, namely the attempt to give a unified description of linguistic units.

Precedent units can occur in the form, the meaning or function. The meaning of the precedent unit is determined by factitive knowledge about an event, an object, an image and its features; it is a question of the derivative of a linguistic unit. Precedent units are not homogeneous in the form as each period of language development contributes to the derivation of a precedent unit. As for the function, it is the expression of the precedent meaning through a grammatical form. Speaking about the form and meaning of the precedent unit, one should understand that any form can facilitate the derivation of the precedent meaning, but not every meaning can change the form.

Among the many linguistic units, which are considered as the precedent units, the modal verbs in German can be ranked among the first. Modal verbs in the German language are subject to rethinking; therefore their interpretation must consider their cognitive and linguistic characteristics. It is known that the form of modal verbs is the same in all their semantic transformations; therefore, one can study the different precedent meanings and speak about their functions which are relevant for cognitive grammar.

The meanings of the modal verbs have a structural system. In the center of this system, there is the prototypical (primary) meaning from which the precedent (secondary) meanings, associated with the prototypical (primary) meaning, are formed.

In cognitive linguistic, another strategy can be applied for the systematization of the precedent grammatical phenomena. A unit of conceptualization of the modal verbs is considered as the concept, which is a format of the grammatical knowledge about the complex of their meanings, communication values and norms of their use which results from the acquisition of communicative experience of a person at different stages of language development. Based on the nature of the transmitted by modal verbs knowledge, one can speak about lexical (non-deictic) and grammatical (deictic) use. Non-deictic use is specific because of modal verbs used for the expression of deontic modality and its types, namely dynamic / physical, volitional and dispositional modalities. The existence of the grammatical precedent for secondary grammatical meaning is used for the expression of epistemic modality.

So linguists are unanimous in the opinion that the modal verbs können, dürfen, müssen, sollen, wollen and mögen are multifunctional by the expression of different modalities.

To trace the transmission of these verbs to the cognitive scripts, which reflect the acquisition of the modal verb precedent meaning and the representation of the relevant modality, is of no less importance.

\section{COGNITIVE SCRIPT}

Historical experience of the functioning of the modal verbs in German shows that they are exposed to the systematic rethinking, built on the contradiction between the grammatical meaning of a form and a context. Therefore, in the explanation and description of the original, as well as precedent (secondary) meaning, realized by the modal verbs, there is a necessity in the existence of certain operational units or models. This model, in the author's opinion, can be a cognitive script.

The idea of cognitive modeling of modal verbs is preconditioned by the desire of researchers to reveal their modal meaning most fully. Thus, as a tool for explaining the meanings of German modal verbs, the metalanguage structure "to be complemented" [7] is used. In particular, H. Brinkmann uses the term "possibility sense" for the description of the meaning "opportunity" [8].

V.I. Karasik understands the cognitive script as a model in the form of a research construct of reality, which is a working tool for studying the essence of the phenomenon in its systemic and functional connections with phenomena of a more general order and closely related phenomena [9].

The author understands the interpretive semantic model of the specific meaning of the modal verb in narrow or wide usage as the cognitive script. The cognitive script presented as modal reading reveals the grammatical meaning of the modal verb, and the meaning, as it is known, is the cognitive basis of the lexical and grammatical meanings of linguistic units and their realizations in the composition of semantic complexes which appear in an utterance [10]. On this basis, for a precedent (derived) meaning of the modal verbs, the concept of the precedent meaning, that is the derivative, is relevant.

It is clear that the cognitive script of a proposition, which is implemented in the modal verb, affects the formation of the precedent meaning.

As a result of rethinking of the initial meanings, the precedent meanings of modal verbs are the subject of consideration of cognitive semantics as a multilevel theory of meanings. The priority of cognitive semantics lies in the fact that it is not limited to only actually language knowledge, it actively uses knowledge of non-linguistic, encyclopedic character and this knowledge forms the meaning of the utterance. It is expedient to trace in this regard the relationship between the realization of precedent meaning by modal verbs and the relevant modalities.

\section{MODAL VERB, ITS COGNITIVE SCRIPT AND RELEVANT MODALITIES}

Each modal verb realizes the cognitive script which is reflected in a number of its modal meanings of non-deictic and deictic ways of usage. The statement containing a modal verb can be correlated with objective-existing circumstances (deontic modality). Besides, modal verbs can express dynamic / physical and volitional modalities. In this case, modal verbs reveal non-deictic way of usage and express modal relations of necessity, possibility and desirability. 
So, for example, the meaning of possibility in a non-deictic way implies usage of the existence of external agencies, which "enables / authorizes" and allows one to perform actions, considering at the same time laws, ethnical norms, rights, etc. The deontic kind of modality can be illustrated by the following examples with the appropriate cognitive scripts:

(1) „Ich sehe oft Kinder, die beim Einkaufen dies und jenes wollen und alles kriegen", ereifert sich Dominique C. Doch ein Kind kann nicht alles haben, so ist es dann auch im Leben." [www.blick.ch]

$\leftarrow$ "I often see kids who want to shop this and that, and get everything", Dominique C says. "But a child can not have everything, so it is in life."

$\leftarrow$ Cognitive script: It is not possible / forbidden that a child has everything.

(2) Es können aber auch Eltern am Gespräch teilnehmen, die erst für einen späteren Zeitraum Betreuungsbedarf haben. [www.sauerlandkurier.de]

$\leftarrow$ But parents who need care later can participate in the conversation.

$\leftarrow$ Cognitive script: It is possible that parents participate in the conversation.

(3) Aber man darf schon nicht neben einem großen Lastwagen stehen. [www.bielertagblatt.de]

$\leftarrow$ But you can not stand beside a large truck. truck.

$\leftarrow$ Cognitive script: It is not allowed to stand beside a big

(4) Lastwagen dürfen den Tunnel ab Samstag 5 Uhr befahren. [www.bielertagblatt]

$\leftarrow$ Trucks should drive through the tunnel for 5 hours on Saturday.

$\leftarrow$ Cognitive script: Trucks are allowed to drive through the tunnel for 5 hours on Saturday.

In the modal relation of necessity, the directive comes from some instance that the sentence is not explicated; it is in the sentence "a null syntactic unit" (the term [11]):

(5) Am Abend sollen beide Seiten $\mathrm{zu}$ einer Vermittlungsrunde zusammenkommen. [www.hallo.news.lu]

$\leftarrow$ In the evening both sides are to gather at a round table.

$\leftarrow$ Cognitive script: It is necessary that both sides gather at a round table.

(6) Eine solche Erziehung muss jene ethnischen Fundamente ansprechen, die die Einheit der Menschenfamilie fördern. [www.vatican.va]

$\leftarrow$ Such education must address those ethnic positions that are encouraged by humanity.

$\leftarrow$ Cognitive script: It is necessary that such education refers to those ethnic positions that encourage humanity.
The deontic interpretation of sollen stems from the widescope and deals with the passive infinitive of the main verb:

(7) Eltern und Schüler der betroffenen drei Schulen im Severinsviertel sollen am Freitag über das weitere Vorgehen informiert werden. [www.ksta.de]

$\leftarrow$ Parents and children of the three schools involved in the Severin district will be informed on Friday about the further action.

$\leftarrow$ Cognitive script: It is requested that parents and children of the three schools involved in the Severin district need to be informed on Friday about the further action.

The modal verb müssen in its usage reveals a grammatical function that is inherent in the imperative mood:

(8) Du musst nur die richtige Melodie finden! [www.nordkurier.de]

$\leftarrow$ You must find the only right melody!

$\leftarrow$ Cognitive script: Search only for the right melody!

(9) Du musst lauter sprechen! [www.mainpost.de]

$\leftarrow$ You should speak louder!

$\leftarrow$ Cognitive script: Speak louder!

Without a doubt, the verbs wollen and mögen served as the prototype for the volitional interpretation of the modality, namely the form of the subjunctive mood of the latter möchte.

(10) Südafrikas Präsident möchte die Sommerspiele in sein Land holen. [www.news.ch]

$\leftarrow$ President of South Africa would like to host the summer Olympic games in the country.

$\leftarrow$ Cognitive script: The President of South Africa wishes to host the Summer Olympic Games in his country.

(11) Die Gäste kommen, einige kennen sich, andere wollen gemeinsam Weihnachten feiern. [www.emsdettennervolkszeitung.de]

$\leftarrow$ Guests come, some get acquainted, others want to celebrate Christmas together.

$\leftarrow$ Cognitive script: [...] others have a desire to celebrate Christmas together.

The modal verb dürfen can also, like the verbs wollen and mögen, express the volitional modality:

(12) Oft habe sie nicht mal in die Schule gedurft - ihre Eltern wollten es nicht. [www.schweiyeryeit.ch]

$\leftarrow$ Often she has not been allowed in the school - her parents did not want it.

$\leftarrow$ Cognitive script: Her parents did not want it.

(13) Natürlich darf in einem Kiosk der kleine Snack für zwischen durch nicht fehlen. [www.sauerlankurier.de]

$\leftarrow$ Of course, the small snack may not be missing in a kiosk. 
$\leftarrow$ Cognitive script: I do not want it. / We do not want it.

The modal verbs können and müssen can express the dispositional modality. In this case, können has the meaning of ability, and müssen has the meaning of the necessity which is revealed in external circumstances. The modal verb können can be considered as a "disposition" of the subject in relation to the complement, interpreting it as "be able" to do something:

(14) Sobald Blumenzwiebeln ausreichend Wärme und genug Wasser haben, können sie austreiben. [www.schwarzwaelder-bote.de]

$\leftarrow$ As soon as flower bulbs have enough heat and enough water, they can sprout.

$\leftarrow$ Cognitive script: As soon as flower bulbs have enough heat and enough water they are able to sprout.

(15) Die Lehrer werden sicher verstehen, dass du Französisch nicht machen konntest. [www.sat1.de]

$\leftarrow$ The teachers will surely understand that you could not learn French.

$\leftarrow$ Cognitive script: The teachers will surely understand that you were not able to learn French.

In turn, the modal verb müssen, expressing dispositional modality, can be interpreted as "to be forced" to do something:

(16) Also muss ich meine Chance woanders $\mathrm{zu}$ suchen. Dem Wiener waren mehrere Angebote aus Italien vorgelegen. [www.tt.com]

$\leftarrow$ So I have to look for my chance somewhere else. Several offers from Italy were presented to the Viennese.

$\leftarrow$ Cognitive script: I am forced to look for my chance somewhere else.

(17) Griechenland muss drastisch sparen, um das Vertrauen in seine Staatsfinanzen zurückzuerlangen. [www.20min.ch]

$\leftarrow$ Greece has much to save again to restore confidence in its public finances.

$\leftarrow$ Cognitive script: Greece is forced to save much.

M. Krifka and B.Vimer indicate the dynamic /physical modality, that is, abilities that are innate or acquired [12, 13].

(18) Noch bevor du auf die Welt gekommen bist, konntest du hören. [www.br-online.de]

$\leftarrow$ Even before you have come into the world, you could hear.

$\leftarrow$ Cognitive script: Even before you have come into the world, you were able to hear.

Deontic, volitional and dispositional modalities determine a condition of the subject in their prototypical usage, namely the condition that is caused by the modal source. This is the core of the meaning, which is common to the three non-deictic modalities, and which can be paraphrased as follows: The subject of the sentence determined by the influence of the modal source is in the modal condition concerning an infinitive (complement).

However, modal verbs in German can express a subjective opinion of the situation, so the author implies the expression of the epistemic modality and the deictic way of usage.

The deictic (epistemic) use of the modal verb dürfen reveals only the form dürfte (Past Simple Subjunctive):

(19) "Die Täter dürften zwischen 18 und 25 Jahre alt und zwischen 180 und $190 \mathrm{~cm}$ groß sein", berichtet die Polizei. [www.stuttgarter-nachrichten.de]

$\leftarrow$ The offenders are between 18 and 25 years old and between 180 and $190 \mathrm{~cm}$ tall", reports the police.

$\leftarrow$ Cognitive script: Probably the offenders are between 18 and 25 years old and between 180 and $190 \mathrm{~cm}$ tall”, reports the police.

(20) Dieses Jahr dürfte der Umsatz 6,7 Milliarden Dollar erreichen. [www.bernerzeitung.ch]

$\leftarrow$ This year sales are expected to reach 6.7 billion dollars.

$\leftarrow$ Cognitive script: This year sales will certainly reach 6.7 billion dollars.

Also in case of a model verb dürfen, epistemic interpretation has a Past Simple Subjunctive form of the modal verb sollen, namely sollte:

(21) Damit sollte dann eine faire Abwicklung zwischen den Konkurrenten im privaten Sektor gewährleistet sein. [www.az.com]

$\leftarrow$ This should guarantee a fair settlement between the competitors in the private sector.

$\leftarrow$ Cognitive script: One states that a fair settlement should be guaranteed between the competitors in the private sector.

(22) Das nächste Geschäft sollte ein Größeres sein. [www.gea.de]

$\leftarrow$ The next business should be a bigger one.

$\leftarrow$ Cognitive script: They say that the next business will be bigger.

The model verb wollen as a marker of the epistemic meaning "assert" is used not only in simple sentences, but also in complex sentences, although the former are easily transformed into the second ones as they contains two predicative cores. In the second case, wollen is in the main sentence and the subordinate clause contains information about what is asserted in the proposition:

(23) Wir wollen, dass die Defizite im Staatshaushalt von allen tschechischen Arbeitnehmern mitgetragen werden, nicht nur von Angestellten im öffentlichen Dienst. [www.radio.ch]

$\leftarrow$ We want the deficits in the budget were covered by all Czech workers and not only by employees of public service.

$\leftarrow$ Cognitive script: Someone expresses his opinion that the deficits in the budget should be covered by all Czech workers and not only by employees of public service. 
The deictic usage of the verbs mögen and können is primarily related to the interpretation with a wide scope and the emergence of the meaning of "total opportunity":

(24) Noch eins: Da mögen die Probleme der Supermacht USA völlig andere sein als jene eines kleinen, nicht sehr bedeutenden mitteleuropäischen Staates. [www.profil.at]

$\leftarrow$ The problems of the Superpower the USA may be completely different from those of a small, not very important Central European state.

$\leftarrow$ Cognitive script: The problems of the Superpower the USA are probably completely different from those of a small, not very important Central European state.

(25) Es mag Personen geben, die ängstlich und misstrauisch sind. [www.faz.net]

$\leftarrow$ There may be people who are shy and suspicious.

$\leftarrow$ Cognitive script: There are probably people who are shy and suspicious.

(26) Als Nachhilfe- und Flötenperson konntest du den Kindern so viel Positives auf ihren Lebensweg mitgeben. [www.dorfposcht.ch]

$\leftarrow$ As a tutor and a flutist you could give a lot of positive on their life to children, but you haven't done it.

$\leftarrow$ Cognitive script: Maybe as a tutor and a flutist you give to children a lot of positive on their life, but you haven't done it.

The verb müssen in a deictic usage objectifies the "assumption":

(27) Gedanke, Wort und Tat müssen übereinstimmen. [www.sat1.de]

$\leftarrow$ The thought, the word and an act should coincide.

$\leftarrow$ Cognitive script: Surely the thought, the word and an act coincide.

Expletive subject "es" and "das" are often used in wordgroups, such as "kann / darf / mag / will / muss / soll sein". The sentences es, das + modal verb have phraseological and metalinguistic structures. They are considered as phraseosyntaxeme of the same type as a simple sentence and transmit the cognitive script of their epistemic modal interpretation. They express "assumption" which is often accompanied by doubts and interrogation:

(28) Es kann aber auch sein, dass sie am Computer sitzt und eine Kurzgeschichte beginnt. [www.gea.de]

$\leftarrow$ It may also be that she sits at the computer and a short story starts.

$\leftarrow$ Cognitive script: It is not excluded that she sits at the computer and a short story starts.

(29) Soll es wahr sein?

$\leftarrow$ Should it be true?

$\leftarrow$ Cognitive script: Really?
A prototypical variant of use of such structures is the modal expression of speaker's mental state - confusion, indignation, reproach, etc.:

(30) Was soll das?

$\leftarrow$ What is this?

$\leftarrow$ Cognitive script: That is not what I expected from you.

(31) Es darf nicht sein, dass "sogenannte Fachkenner" die Frechheit besitzen, sich zum gesellschaftlichen Generalthema zu äußern. [www.morgenweb.de]

$\leftarrow$ It must not be that "so called professionals" have the audacity to comment on the society's general theme.

$\leftarrow$ Cognitive script: It is outrageous that "so called professionals" have the audacity to comment on the society's general theme.

The existence of two modal interpretations, deontic and epistemic, allows one to speak about the German modal verbs in a semiotic aspect (non-deictic / deictic) at the level of their polysemy, and their semantic interchangeability - at the level of synonymy.

The polysemy will be explained in this article for example with the modal verb sollen. In diachrony and synchrony, this modal verb can express a requirement, urgent advice or necessary condition and a reference of the words of others:

(32) "Erst nach dem Essen sollst du trinken" Generationen von Kindern haben diesen Satz zu hören bekommen. [www.morgenpost.de]

$\leftarrow$ "Only after you eat, you shall drink" - generations of children have got this sentence to hear.

$\leftarrow$ Cognitive script: You are forced to drink until after the meal.

(33) Hallo, Valentina, du solltest dich im Alltag ausreichend bewegen. [www.20min.ch]

$\leftarrow$ Hello Valentina, you should move sufficiently in everyday life.

$\leftarrow$ Cognitive script: Valentia is advised to move sufficiently in everyday life.

(34) Wenn es also eine Modernisierung geben soll, um das Skigebiet attraktiver zu machen, so müsste man dafür sorgen, dass die Pisten besser präpariert werden. [www.ovb-online.de]

$\leftarrow$ If there is to be a modernization in order to make the ski area more attractive, so you would have to ensure that the slopes will be better prepared.

$\leftarrow$ Cognitive script: If a modernization is necessary in order to make the ski area more attractive, so you would have to ensure that the slopes will be better prepared.

(35) Der Augsburger Bischof Walter Mixa soll Heimkinder körperlich gezüchtigt haben. [www.news.ch]

$\leftarrow$ The Augsburg Bishop Walter Mixa had to have punished children physically. 
$\leftarrow$ Cognitive script: It is said that the Augsburg Bishop Walter Mixa had punished children physically.

From the point of view of synonymy, a certain cognitive context motivates the interchangeability of modal verbs, for example dürfen:

(36) Wie das geht, wissen wir eigentlich alle: Du sollst nicht rauchen, so lautet das erste Gebot. [www.bilanz.ch]

$\leftarrow$ How to do this we all don't know: you shan't smoke, so the first Law is.

$\leftarrow$ Cognitive script: Du darfst nicht rauchen. - You are not allowed to smoke.

The modal verb wollen in the meaning of "necessity" forms a synonym to müssen and is its stylistic variant and express the necessity to perform action:

(37) Eine persönliche Spendenstrategie will aber gut überlegt sein. [www.gea.de]

$\leftarrow$ A personal giving strategy needs to be thought out well.

$\leftarrow$ Cognitive script: Eine persönliche Spendenstrategie muss aber gut überlegt sein. - A personal giving strategy must be well thought out.

Without a doubt, it is possible to say that the modal verbs have several meanings among which are the main meaning and a few other typical meanings, namely precedent meanings. Depending on the speech situation and the context, the modal verbs can substitute for each other and, on this basis, are synonyms.

The system analysis of prototypical meanings of modal verbs allows us to state two kinds of their use - non-deictic and deictic. Within the first method, the modal relation of an opportunity characteristic for the verbs können and dürfen, necessity for müssen and sollen is realized. The modal relation of desirability contains the modal verbs wollen and mögen, that is, one can speak of the volatile modality. Within the second method, the modal relation of the assumption is realized in its various semantic aspects.
Revealing the functional relevance of the cognitive script for the realization of the semantics of modal verbs has shown that for the such cognitive script as a modal reading of the proposition in which the modal verb is realized, contextual conditioning is actual. The latter, in the form of a wide or narrow scope, influences the formation of the cognitive script, and as a consequence, the formation of the precedent meaning of the modal verb.

\section{References}

[1] N. Golubeva, "The cognitive basis of grammatical precedet units as a vategory," Materials of the conference, 9-12 April 2013, SPb: NestorHistory, 2013, pp. 46-49.

[2] N. Golubeva, "Precedent concerning as a cognotove projection," Cognitive studies of language, vol. XXI, pp. 47-52, 2015.

[3] N. Boldyrev J. "Cognitive semantics. Introduction to cognitive linguistics: course of lectures", 4rd ed., Tambov: Publishing house named after G.R. Derzhavin, 2014, 236p.

[4] E. Kubryakova, "In search of the essence of language," Issues of cognitive linguistics, No. 1, pp.5-13, 2009.

[5] E. K. Kubryakova, Brief dictinory of cognitive terms, M: Philological faculty of Moscow state University M.V. Lomonosov, 1997, 245p.

[6] T. Skrebtsova, "History og cognitive linguistics," Questions of linguistics, No. 6, pp. 153-155, 2009.

[7] J. Erben, Essay of German grammar, $9^{\text {th }}$ ed., Berlin: AkademiePublishing house, 1966, $316 \mathrm{p}$.

[8] H. Brinkmann, The German language. Characters and performance, Düsseldorf: Schwann, 1962, 334 p.

[9] V. Karasik, Language matrix of culture, M: Gnosis, 2013, 320 p.

[10] A. Bondarko, Grammatical category and context, L.: Science, 1978, 115 p.

[11] E. Kirov, Theoretical problems of th languuage modeling, Kazan:Publihing house of Kazan university, 1989, $256 \mathrm{p}$.

[12] M. Krifka, "The semantics" institute for German language and linguistics, Humboldt-University, Berlin, 2007, pp. 54-56.

[13] B. Wiemer, "Introduction to linguistics," lectures, vol. 3, 2004-2005, Language source: Project of German Vocabulary - www.wortschatz.unileipzig.de 